\title{
Campaigning across continents: how Latin American parties link up with migrant associations abroad
}

\author{
Nicolas Fliess (D)
}

Correspondence: n.fliess@sussex.ac. uk

University of Sussex, Brighton, UK

\begin{abstract}
Emigrant voting rights have opened new electoral arenas, and many political parties increasingly campaign across borders. Yet relatively little is known about the challenges parties confront when campaigning transnationally and the strategies they have developed in response to these challenges. This paper addresses these shortcomings. First, I investigate the hurdles Latin American parties face in linking up with organized migrant collectives in residency countries for campaigning purposes. Second, I probe into the transnational linkage strategies these parties deploy to tap into migrant associations' resources and mobilization capacities. This study builds on a comparative research design and draws on almost 40 semi-structured interviews with Bolivian and Ecuadorian party activists as well as association leaders in Barcelona, Spain. Departing from the party interest group literature, I identify three transnational linkage strategies Bolivian and Ecuadorian parties implement: 1) Infiltration, 2) Co-optation, and 3) Cooperation. All parties execute these tactics informally in order to comply with local norms that require associations to remain apolitical. The analysis further demonstrates that differences between home-country electoral systems shape the types of linkage strategies Bolivian and Ecuadorian parties use. This article contributes to the study of migrant politics and political parties in important ways. This study highlights how political parties actively negotiate their entry into the transnational electoral arena, and sheds light on how migrants remain politically connected to their home countries.
\end{abstract}

\section{Introduction}

In many countries, cross-border political activities increasingly shape domestic politics. The "globalization of domestic politics" has transformed emigrant communities into new constituencies (Koslowski 2005). In an effort to mobilize these communities' electoral, economic and human capital, political parties have begun reaching out to them (Bermúdez 2016; Burgess 2018; Escrivá et al. 2010; Hammond 2012; Itzigsohn 2000; Kernalegenn and van Haute 2020; Landolt et al. 1999; Levitt 2001; Mügge 2010; Østergaard-Nielsen 2003; Østergaard-Nielsen and Ciornei 2019; Paarlberg 2019; Schütze 2016; M. P. Smith and Bakker 2008; R. C. Smith 2003; Yener-Roderburg 2020). In this context, migrant associations in residency countries operate as important

(c) The Author(s). 2021 Open Access This article is licensed under a Creative Commons Attribution 4.0 International License, which permits use, sharing, adaptation, distribution and reproduction in any medium or format, as long as you give appropriate credit to the original author(s) and the source, provide a link to the Creative Commons licence, and indicate if changes were made. The images or other third party material in this article are included in the article's Creative Commons licence, unless indicated otherwise in a credit line to the material. If material is not included in the article's Creative Commons licence and your intended use is not permitted by statutory regulation or exceeds the permitted use, you will need to obtain permission directly from the copyright holder. To view a copy of this licence, visit http://creativecommons.org/licenses/by/4.0/. 
gatekeepers. They act as direct bridges to these communities and possess local resources, and thus can boost the transnational outreach capacity of political parties. This article examines the strategies Bolivian and Ecuadorian parties have developed to link up with migrant associations during electoral campaigns.

Transnational campaign linkages between political parties and migrant associations are a global phenomenon (Hammond 2012; Klekowski von Koppenfels 2013; Lafleur 2013 Ch. 6; Landolt et al. 1999; Mügge 2010; Østergaard-Nielsen 2003; Paarlberg 2019, p. 547; Schütze 2016; M. P. Smith and Bakker 2008; R. C. Smith 2003; YenerRoderburg 2020). Political party research abroad regularly mentions these linkages but often only in vague terms. One reason is that scholars have tended to analyze parties and migrant organizations separately. Hence, while many studies acknowledge the existence of these connections, we know surprisingly little about how they arise. Transnational migrant associations, on the other hand, have mainly been studied as vehicles for immigrant demands or development projects (Morell Blanch 2005; Escobar 2010; Portes and Fernández-Kelly 2015), but not as partners to political parties during election campaigns. However, to better understand how parties negotiate their access to the transnational electoral arena, we must examine both actors together.

A few works have made important inroads into studying the transnational links between parties and migrant associations. These studies have either focused on settings with transported home country conflicts (Hammond 2012; Mügge 2010; ØstergaardNielsen 2003; Yener-Roderburg 2020), or analyzed these connections in light of codevelopment programs (Burgess 2012; Schütze 2016; M. P. Smith and Bakker 2008; R. C. Smith 2003). Nevertheless, very little is known about the tactics parties use to connect with migrant associations during campaigns, and how these strategies vary by party, or across countries. This article sets out to address this knowledge gap by answering the following questions: What strategies do political parties use abroad to connect with migrant organizations during election campaigns? Why do parties choose one strategy over another? How do parties implement these strategies?

The relationship between political parties and civil society actors has received notable attention in political science (Allern 2010; Poguntke 2006; Scarrow et al. 2017; Schwartz 2005; Thomas 2001; Verge 2012). Taking this literature as a point of departure, I identify five strategies parties can use to link up with migrant associations abroad: 1) establish formal alliances, 2) create their own groups, 3) infiltrate migrant associations, 4) co-opt migrant organizations, and 5) create forums of collaboration to establish exchange relationships. In this article, I investigate the extent to which parties utilize these strategies in the transnational electoral arena.

Bolivia and Ecuador permit campaigning abroad and each country accounts for a sizeable and enfranchised emigrant electorate. The most similar research design holds constant important political, socio-cultural, and migration-specific variables. An important difference between the two countries' electoral systems is that only Ecuador grants special representation to emigrants. This study draws on 38 qualitative interviews with party activists and migrant association leaders in Barcelona, Spain, as well as several participant observations.

The results demonstrate that Bolivian and Ecuadorian parties do not formalize alliances with migrant organizations, nor create their own associations abroad. However, they do infiltrate, co-opt, and collaborate with them. Some parties apply these 
three linkage strategies simultaneously. Bolivian parties mainly use infiltration tactics, and occasionally engage in collaboration. In contrast, Ecuadorian parties deploy a multi-layered set of strategies involving infiltration, co-optation, and collaboration. The difference between the countries' electoral systems is essential to explaining this variance. Ecuador's system of special representation equips political parties with valuable resources for co-opting association leaders and creating meaningful forums for collaboration. In comparison, Bolivian parties lack similar resources and must rely more on infiltration tactics. I claim that parties execute their linkage strategies informally, enabling them to tie in migrant association leaders on a personal level. In this way, parties overcome local norms that would hinder associations in Barcelona seeking to engage with political home country parties on an institutional level.

This article offers several important insights into the study of political parties and migrant politics. It contributes to our understanding of how political parties adapt to a globalized electorate. Transnational campaign trails are complex; parties do not simply cross borders and set up a campaign in another country. Parties must actively negotiate their entry into, and presence within, migrant communities. They frequently face resistance and require specific strategies to gain a foothold abroad. Unpacking this process is important, as it allows us to better understand how parties aim to mobilize migrant voters and simplify their vote choice. These are core functions of political parties (Dalton and Wattenberg 2002) and undergird the processes by which migrants remain politically connected to their home country (Bermúdez 2016; Escobar and Gómez Kopp 2014; Escrivá et al. 2010; Levitt 2001; M. P. Smith and Bakker 2008; R. C. Smith 2003). Furthermore, this study highlights and problematizes parties' connections to local actors in residency countries, feeding into other work that seeks to explain variance in transnational party outreach (Kernalegenn and van Haute 2020; Østergaard-Nielsen and Ciornei 2019; Paarlberg 2019).

The next two sections present the studies' theoretical foundations. Subsequently, I introduce the research methods. A comparative analysis of Bolivian and Ecuadorian linkage strategies in Barcelona follows. The article concludes with some final remarks.

\section{The challenges of transnational campaigns and how parties tackle them}

The global extension of voting rights to emigrants (Collyer 2014; Palop-García and Pedroza 2017) has pushed many political parties into new electoral arenas (ØstergaardNielsen and Ciornei 2019). Studies on political parties in exile demonstrate that the transnationalization of political parties is not a new phenomenon (see for example Shain 1989 Ch. 2). What is new, however, is the scale on which this trend has taken root today in new and established democracies, and the growing scholarly interest it has spurred (Kernalegenn and van Haute 2020). I use transnationalism to refer to the "recurrent institutionalized interactions and exchanges between, on the one hand, immigrants and their social and political organizations and, on the other hand, the political institutions and the state apparatus of the country of origin" (Itzigsohn 2000, p. 1130).

Political parties face serious challenges to mobilizing across borders. For one, the outreach capacity of parties is confined by limited campaign resources and national media coverage abroad, as well as an electorate that usually spans several countries. Second, emigrants do not always welcome these parties; often, they blame the political elite for 
their emigration (Shain 1989). Previous work has emphasized how parties can gain ground abroad by recruiting migrants with previous political experience and by linking up with 'sister' parties, social movements and trade unions in the host country (Bermúdez 2016 Ch. 6; Lafleur 2013, pp. 126-128; Østergaard-Nielsen and Ciornei 2019). Similarly, political parties can build on migrant associations abroad (Hammond 2012; Klekowski von Koppenfels 2013; Lafleur 2013 Ch. 6; Landolt et al. 1999; Mügge 2010; ØstergaardNielsen 2003; Paarlberg 2019, p. 547; Schütze 2016; M. P. Smith and Bakker 2008; R. C. Smith 2003; Yener-Roderburg 2020).

In authoritarian countries, regime parties draw on migrant organizations abroad to mobilize supporters, secure financial backing, or survey oppositional forces in exile (Hammond 2012; Mügge 2010; Østergaard-Nielsen 2003). Elsewhere, migrant associations can help parties increase their visibility, mobilize voters, establish trust and provide valuable local resources. Sometimes migrant associations serve political parties to camouflage their activities when the origin state prohibits campaigning abroad (Mügge 2010, p. 156). Not all associations are transnationally active, however; nor do all associations engage in political activities (Morell Blanch 2005; Escobar 2010; Morales and Jorba 2010). Hence, parties require thoughtful strategies to link up with migrant organizations.

\section{An analytical framework}

The party - interest group link has always shaped the organizational character of parties (Kirchheimer, 1966). Political parties and civil society organizations continue to be linked nowadays in a variety of ways (Allern 2010; Poguntke 2006; Scarrow et al. 2017). Most commonly, scholars look to statutory indicators, such as overlaps in corporate memberships, formal group affiliations, representation rights, or formal access to decision-making bodies in order to deduce institutional connections between parties and civil society groups. For Schwartz (2005) these formal alliances or affiliations represent a party strategy to forge ties with groups the party views as "central to its mission and critical to its self-definition" (p. 41). In the transnational context, this can mean parties extending representation and full membership rights to their activist groups abroad (Landolt et al. 1999, p. 310).

Allern (2010) points out, however, that so-called 'unorganized links for contact' play an important role too. The work delineates how parties and interest groups in Norway generate linkages through unofficial, personal contacts between individual representatives and spokespeople. This finding resonates with social movement research that highlights the importance of overlapping social networks in generating interorganizational connections (Kitschelt 1989). Verge (2012) argues that political parties consciously draw on these informal connections as part of their strategy to connect with civil society organizations. The study demonstrates that Spanish parties rely on four different types of strategies to establish links with interest groups: creating groups, infiltration, co-optation, and collaboration. Parties apply these strategies informally and formally.

The creation of their own social groups allows parties to target specific social segments, anchor the party in society, and overcome weak party membership (Poguntke 2006; Verge 2012). Infiltration tactics include party members entering the executive board of an association or affiliating with an association as individuals. This informal 
overlap in membership recalls Allern's (2010) 'unorganized links for contact.' Infiltration allows parties to "locate their agents openly or covertly in citizen organizations" (Lawson 1980, p. 11). Once inside the association, party activists encourage association members to join the party organization. Alternatively, parties can co-opt associations by recruiting their leaders for party posts or public offices. This strategy allows parties to mobilize supporters, exclude opponents, and recruit skilled government servants or party employees (Schwartz 2005; Verge 2012). Verge (2012) assumes that "the larger the reach and depth of political appointments in a country, the more likely it will be to apply co-option" (p. 56), though the study was unable to test this assumption because of the limitations a single-country study design imposes. At the same time, cooptation presents an opportunity for organized migrant collectives to place their members in government (Lawson 1980).

Moreover, parties establish formal and informal forums of contact that promote collaboration with civil society organizations (Allern 2010; Verge 2012). One example would be an invitation to a party meeting to gather migrant demands for an electoral program. These encounters allow parties to offer specific benefits to interest groups, potentially resulting in an exchange relationship. Put simply, parties provide access to legislation and policymaking in exchange for votes, fundraisers, and organizational assistance (Schwartz 2005; Poguntke 2006; Allern 2010). The promise of a "policy responsive linkage" (Lawson 1980) ties the civil society group to the political party. In countries with a strong sending state outreach, parties may exploit transnational co-development or culture programs to create forums and initiate these collaborations (Burgess 2012, 2018; Landolt et al. 1999; M. P. Smith and Bakker 2008). Importantly, the strategy of luring associations with policy pledges must be separated from parties' 'linkage by reward,' which involves "a much more pragmatic relationship with their supporters: votes for favors" (Lawson 1980, p. 17). For example, the Mexican government party used linkages by reward abroad until other parties began seriously challenging the oneparty system (Schütze 2016, Ch. 5; R. C. Smith 2003).

Five main linkage strategies emerge from a review of the literature: formal alliances or affiliations, the creation of social groups, infiltration, co-optation, and collaboration (exchange relationships, linkage by reward). Parties can choose to deploy none, some, or all of these strategies abroad. They must decide whether to execute these strategies formally or informally (except for formal alliances, which are formal by definition). Authors such as Thomas (2001) and Verge (2012) acknowledge the difference between formal and informal linkages but remain vague on how and why parties choose one over the other. Allern (2010) argues that informal contacts and personal overlaps represent a 'weaker kind of link' (p. 59). While this might be true in the Norwegian case (Allern 2010) and in other Western democracies (Poguntke 2006, p. 399), the transnational Latin American context requires a different perspective, as parties and party systems are far less institutionalized. Bolivia and Ecuador contain some of the weakest party systems in the region (Mainwaring 2018). Poorly rooted in society and having little organizational capacity, their parties often only exist for short periods of time (Levitsky et al. 2016). This makes formal linkage strategies more difficult to execute. Informal contacts, in contrast, can be more easily established, and offer more flexibility for parties and representatives of interest organizations alike (Schwartz 2005, p. 44). 


\section{Determinants of transnational party - association linkages}

The existing literature stresses various factors that shape the relationships between political parties and interest groups. In particular, structural and institutional determinants are crucial to explaining differences in how parties from different countries behave towards interest groups (Allern 2010, pp. 98-101; Thomas 2001, pp. 16-17). The role of national political institutions therefore merits further consideration here.

The electoral system is an essential structural factor that regulates parties' freedom to maneuver and influences their activities in the transnational electoral arena. Countries around the world significantly differ in their emigrant enfranchisement practices (Collyer 2014). First, countries vary according to the type of elections they organize abroad. For example, while Bolivian emigrants can vote in presidential elections, Ecuadorian emigrants are enfranchised in presidential and legislative elections. National and legislative elections in Ecuador are held on the same day. Ecuadorian parties thus have the extra incentive of being able to run a single campaign to secure emigrant votes for two elections. Second, the impact of emigrant votes on election outcomes also depends on the electoral system. Electoral systems that reserve extra-territorial seats in the parliament raise the stakes for political parties to campaign abroad, as their efforts can directly translate into parliamentary seats (Kernalegenn and van Haute 2020; Østergaard-Nielsen and Ciornei 2019). In contrast, the impact of the external vote in presidential elections is often less visible, even negligible, in the absence of narrow elections. Third, electoral systems with extra-territorial representation offer additional resources to parties in the form of assembly candidate list places, which parties can use to co-opt migrant association leaders and tap into their resources and mobilization potential.

National political culture is another important determinant of the relationship between political parties and civil society groups. While much of the literature on party interest groups is concerned with the factors that enhance and shape existing relationships between parties and civil society groups, less attention has been devoted to the factors that hinder these connections. Thomas (2001, p. 273) defines political culture as "a shared set of knowledge, attitudes, and symbols that help to define the procedures and goals of politics." In his view, a political culture characterized by skepticism or antipathy towards political parties or the government can hamper the development of party-interest group relationships (Escobar 2010). This can include local community norms that disapprove of migrant associations engaging with political parties. Other authors have adopted a more rational cost-benefit perspective that delineates how interest groups seek to distance themselves from political parties when maintaining a relationship would risk disadvantaging them (Allern 2010). In summary, we can expect relationships between parties and migrant associations to be shaped by the electoral system of the home country and the political culture of the residency communities.

\section{Research design}

This study is grounded in a most similar research design examining Bolivia and Ecuador. The case selection follows 'geographical area lines', a strategy to balance a "homogenous milieu in more than one respect: history, culture, level of development" (Dogan and Pelassy 1984, p. 118). Table 1 displays the similarities between both countries that allow 
Table 1 Country Characteristics

\begin{tabular}{lll}
\hline & Bolivia & Ecuador \\
\hline Freedom House Index (2018) & $67 / 100$ (partly free) & $60 / 100$ (partly free) \\
$\begin{array}{l}\text { Perceptions of Electoral Integrity } \\
\text { (last elections) }\end{array}$ & $50 / 100$ & $46 / 100$ \\
Incumbent President's Party & MAS-IPSP (2006-2019) & Alianza País (2006 - present) \\
Gini Index (2018) & 42.2 & 45.5 \\
GDP per capita (2018) & 3351.12 & 6213.87 \\
Remittances as \% of GDP (2018) & $3.4 \%$ & $2.8 \%$ \\
\% abroad of the total population & $7.46 \%$ & $6.83 \%$ \\
Main settlement countries & Argentina, Spain, USA, Brazil & USA, Spain, Italy \\
\% of the emigrant population & $19.34 \%$ & $38.27 \%$ \\
that resides in Spain & & \\
Migration history to Spain & $2002-2009$ & Two Phases: Late 1990s-2004 and 2007-2010 \\
Main destinations in Spain & Barcelona, Madrid, Murcia & Madrid, Barcelona, Murcia \\
Background & Rural & Urban - rural \\
Skill Level & Medium-low & Medium-low \\
Sex Ratio & $39 \%$ Men & $47 \%$ Men \\
& $61 \%$ Women & $53 \%$ Women \\
\hline
\end{tabular}

Sources: Cebolla-Boado and López-Sala 2015, p. 269; Freedom House Index 2018; Hinojosa 2008, 2009; Estatistica INE 2016; United Nations 2015; World Bank 2018a, 2018b; Norris and Grömping 2019

us to hold constant an array of potential independent variables. Both Andean countries report similar democracy and electoral integrity scores. Since 2006, the same leftist parties have been governing each country. Although Ecuador reports a higher GDP than Bolivia, inequality levels are at similar levels, and remittances make up an important share of both economies. Furthermore, both countries are characterized by similar migration patterns to Europe, including a similar socio-demographic composition of their communities in Spain. These characteristics indicate that Bolivian and Ecuadorian migrants in Spain collectively organize in associations to meet similar community needs (Morell Blanch 2005; Morales and Jorba 2010). Finally, studying several groups in one setting, Barcelona, allows us to focus on host country-related variables, such as local norms and emigrants' attitudes towards political home country actors. Importantly, foreign parties are free to organize and campaign in Spain.

Bolivia and Ecuador differ in their electoral systems. In Ecuador, emigrants are enfranchised in presidential elections, legislative elections, and national referendums. Moreover, Ecuador exclusively reserves six out of 137 seats in the national parliament for emigrant MPs. The Ecuadorian communities in Europe, Asia and Oceania elect two of these seats. Bolivia, in contrast, does not allow for extra-territorial representation and grants the right to vote from abroad only in presidential elections and national referendums (see Table 2).

\section{Data collection methods}

Fieldwork was carried out in Barcelona between February 2018 and February 2019. The first step involved identifying which Bolivian and Ecuadorian parties had previously been campaigning in Barcelona on-site. However, directories with contact information of foreign party representatives in Barcelona do not exist. Moreover, emails to parties 
Table 2 The Electoral Systems of Bolivia and Ecuador

\begin{tabular}{lll}
\hline & Bolivia & Ecuador \\
\hline Presidential Elections & $\checkmark$ & $\checkmark$ \\
(First Time) & $(2009)$ & $(2006)$ \\
National Legislative Elections & $X$ & $\checkmark$ \\
(First Time) & & $(2007)$ \\
Special Representation & $X$ & $\checkmark$ \\
(First Time) & & $(2007)$ \\
National Referendum & $\checkmark$ & $\checkmark$ \\
(First Time) & $(2016)$ & $(2008)$ \\
Vote Occasions abroad (Number of election days)* & 4 & 8 \\
Voting Modality & In person (in consulates) & In person (in consulates)
\end{tabular}

Sources: ACE 2019; Consejo Nacional Electoral Ecuador CNE 2018; Organo Ectoral Plurinacional Bolivia OEP 2018; PalopGarcía and Pedroza 2017

*Ecuador holds presidential and legislative elections on the same day

in Bolivia and Ecuador went unanswered. Therefore, entry into the field could only be gained through contacts on the ground, which I established at events organized by the consulates or migrant associations. Snowball sampling helped generate further contacts. To be selected, parties needed to have an official representative in Barcelona. This study identified two Bolivian parties: MAS-IPSP (incumbent, leftist) and Frente de Unidad Nacional, UN (main opposition party, conservative). In the case of Ecuador, 15 parties had fielded candidates for the 'European' constituency in the 2013 and 2017 elections, and an additional selection criterion was necessary to reduce the sample to a manageable size. Hence, Ecuadorian parties needed to have contested both previous elections to be included. Four parties fulfilled this criterion: Alianza País (incumbent, leftist); CREO; Partido Social Cristiano (PSC); and SUMA (main opposition parties, conservative). The over-representation of Ecuadorian parties in this study reflects the slightly more institutionalized Ecuadorian party system, on the one hand, (Mainwaring 2018), and the Ecuadorian electoral system's extra-territorial representation on the other hand, which tends to spur transnational party outreach (Kernalegenn and van Haute 2020; Østergaard-Nielsen and Ciornei 2019).

To select migrant associations for inclusion, an association census was set up, drawing from official registers. Since these registers are not frequently updated, I developed four indicators to identify the most active associations. First, I examined whether an association is enrolled in various public registers. Second, I consulted press articles and online appearances (e.g., Facebook and Webpages). Third, I frequented cultural events in the city to conduct participant observations. Fourth, I presented the preliminary association census to interviewees, asking them which were still active and to what extent. I then triangulated their answers with the other sources mentioned above. A Bolivian or Ecuadorian migrant association is defined as such when (1) it is formally registered as an association, (2) the majority of the board consists of immigrants of Bolivian or Ecuadorian nationality, and (3) its activities are non-profit motivated.

The interviewee selection process followed a purposive sampling method. In total, I conducted 38 semi-structured elite interviews in Spanish for $1.5 \mathrm{~h}$ each on average. I interviewed 15 party activists from six parties, including two elected Ecuadorian emigrant MPs. The main topics included their individual political and associative 
trajectories, the relationships their parties maintain with associations, how these contacts are initiated, and the difficulties they encounter in doing so. The sample of migrant associations includes 23 migrant association/federation leaders. These interviews were conducted until saturation was reached. The questions concerned the main activities of the associations, how they organize, the associations' general political involvement, their relationships with home country parties, and attempts of home country parties to establish contact and to receive their support. Finally, participant observations during consulate and cultural/folklore dance events presented fruitful opportunities to informally engage in conversations about the relationship between migrant associations and parties.

\section{Parties and associations during elections: dependence and disinterest}

Electoral mobilization across continents is a difficult endeavor. First, parties face logistical challenges. The last Bolivian and Ecuadorian presidential elections were organized abroad in 33 and 47 countries, respectively, rendering a comprehensive transnational party outreach effort quite difficult. Parties work with tight campaign budgets, and most of their resources are devoted to the domestic campaigns. While all six parties have occasionally covered some of the campaign material or advertisement costs of their party chapter in Barcelona, only two campaign teams additionally received money directly from the homeland. All party chapters heavily relied on the local support from their militants and sympathizers in Barcelona. Second, studies have documented how migrants lose interest in home country politics over time (e.g. Bermúdez 2016; Escobar 2010). Indeed, all party representatives emphasized the difficulties they encounter in rousing their compatriots' interest in home country politics. Third, some host country authorities prohibit foreign political campaigns (Lafleur 2013, pp. 141-143). The home country parties in this study, however, did not encounter this issue. In fact, a few maintain a somewhat close relationship with host country parties, who assist with active ground support in campaigns.

Given these challenges, political parties require the support of local actors, such as migrant associations, who can bridge the gap between parties and the emigrant electorate. Parties can tap into associations' networks to transmit campaign messages or recruit volunteers (Poguntke 2006; Verge 2012). In turn, migrant associations use parties for their own objectives (e.g. Schütze $2016 \mathrm{Ch}$. 5). Yet, contrary to what the literature would predict, most Bolivian and Ecuadorian migrant associations in Barcelona remain reluctant to partner with home country parties. In interviews with migrant leaders, three main rationales emerged. First, associations are united by a shared sense of belonging or a common goal, but members of the same association may hold different political views. Thus, to avoid internal conflicts, associations tend to evade partnerships with political parties. A non-partisan image also helps associations remain open to the broader community. Second, Bolivian and Ecuadorian associations in Barcelona primarily engage in cultural and sports activities and consider themselves apolitical. In fact, many respondents referred to their association's statute that forbids any political activism. Hence, these organizations have little interest in engaging with political parties. This raises questions as to how migrants' participation in an association can foster their transnational political engagement (Escobar and Gómez Kopp 2014). Finally, while some associations frequently engage in civic work, the majority direct their activities 
strictly towards migrants' needs regarding the host country. For example, they provide juridical assistance, organize workshops on gender violence, or march for immigrant rights. Home country parties are not as relevant to these efforts.

\section{Bolivia}

The analytical framework suggests Bolivian parties could draw on at least five different linkage strategies. The transnational context, however, sets different parameters, and parties adapt accordingly. Consequently, Bolivian parties mainly use infiltration tactics. In a strict sense, infiltration refers to partisans entering migrant associations and penetrating them from the inside (Verge 2012). However, in practice, this process is less straightforward. Many migrants engage in associations to meet compatriots who share their appreciation for the home country's culture, and who can empathize with their experience of living in a foreign country (Morell Blanch 2005). In this regard, emigrant partisans do not join an association because of an ulterior political motive. However, once elections approach, partisans begin mobilizing people in their networks. For partisans who are active in an association, this means talking to fellow association members. Meanwhile, partisans who are not active in an association seek to mobilize acquaintances and friends who are active members. The Bolivian association world in Barcelona is small, and only a few associations have more than 50 members. In this setting, social networks commonly intersect informally. Well-connected partisans take advantage of their networks. In the words of the UN's general secretary in Barcelona, "You go and search for the support of the associations. You always find some contact." They talk to association members face-to-face at events, call the association leaders in their address books, or add them to WhatsApp groups to disseminate campaign messages and invitations to party meetings. Occasionally, they win them over as campaign volunteers; or, in the case of the UN, certify them as party delegates for polling booths on election day.

Most association members and presidents simply decline the parties' requests in order to maintain an apolitical image. For this reason, Bolivian parties do not maintain formal alliances with any associations in Barcelona. Instead, they approach association members and presidents informally. As one of the MAS-IPSP campaign helpers explained, "There are some comrades who have closer, and more personal relationships with those people [of the associations]," and they forge those linkages individually.

The small campaign budgets seldom permit Bolivian parties to organize campaign events in Barcelona, so they have developed a different approach. On weekends, they 'crash' cultural and sports events organized by the associations. Campaign teams appear, often uninvited, and distribute campaign material, or rope spectators into conversations about the upcoming elections.

They always come. They sneak in, camouflaged, or they come and distribute publicity. There is little you can do. Obviously, look, we can tolerate this when they are respectful.

Ariel, Asociación Casa de Bolivia en Catalunya

Thanks to their well-networked members, parties learn about the times and locations of these events. Eventually, these become large gatherings, and parties can easily target 
concentrated groups of potential voters. In 2016, parties were fortunate that the referendum campaign coincided with the annual carnival event. The MAS-IPSP campaign team approached dancers at the march, who were wearing their traditional garb, and took pictures with them. Later, they shared them on Facebook. The party's rationale was to create the impression they enjoyed the association's institutional support, though the group of dancers in the picture only represented a fraction of the association's member base.

Occasionally the MAS-IPSP and UN host events during campaigns themselves. As part of their infiltration strategy, partisans urge association leaders and members to participate. Moreover, they formally invite associations to assist with bands and dance performances. Interviewees from both parties emphasized the importance of combining campaign events with cultural festivities to increase attendance. By attracting less politically interested attendees, campaigners hope to tap into the wider networks of the associations. However, most association representatives stated they decline these invitations in order to maintain their apolitical image. Declining, they said, had no negative consequences.

The strategy of collaboration implies that parties create venues to meet with associations (Verge 2012), or alternatively, that parties approach associations and offer to promote their demands in turn for their support (Lawson 1980; Allern 2010). This can entail a promise to provide common goods to the emigrant community.

One example, if tomorrow a Bolivian party contacts our association with a proposition, we ask them about their objectives, and if it is for the common good we'll support them. $(. .$.$) we transmit the information we receive to others, other collectives and$ other platforms.

Alejandro, president of the Asociación Espiritu de Santa Cruz de la Sierra

Bolivian parties face difficulties implementing this strategy because they lack credibility among many migrant leaders. Some migrant leaders have complained that parties often approach them empty-handed, demanding their vote without showing interest in their needs.

'Linkage by reward' (Lawson 1980) constitutes a sub-set of a collaboration strategy, mainly involving friendly favors in exchange for support. There is some indication that the MAS-IPSP main party body in the homeland has pursued this type of linkage strategy in Barcelona. The party has previously used the consulate in Barcelona, which is manned with committed government partisans. Since 2013, a Bolivian law has eased the 'parachuting' of party militants into diplomatic positions (Ley $\mathrm{N}^{\circ} 465$ ). The previous Consuls in Barcelona, Alicia Muñoz (2011-2016) and Marcelo Poma (2017-2018) were a former Minister of Interior and a former regional MP for the MAS-IPSP party, respectively. Consuls and consulate staff commonly participate in the governing party's activities in Barcelona. Indeed, previous election campaigns have been partially coordinated with the consulate, which also seems to have occurred most recently in Madrid. ${ }^{1}$ For this reason, association leaders frequently equate the consulate with the MAS-IPSP party.

${ }^{1}$ https://www.lavozdetarija.com/2019/03/05/activistas-denuncian-uso-indebido-de-recursos-publicos-en-laembajada-de-bolivia-en-espana/, accessed 21.01.2021. 
In 2014, some weeks before election day, discontent in the Bolivian migrant community about mistreatment in the consulate, and dissatisfaction about exclusive relationships the consulate maintained with certain association leaders, culminated in several street protests that lasted for days. Curiously, the protest united various association leaders, militants of the local MAS-IPSP party cell, and opposition figures, who joined the protest demanding the resignation of Consul Muñoz, accusing her of having "divided the Bolivian community" in Barcelona. Some protesters even organized a hunger strike in front of the consulate, causing major newspaper outlets in Bolivia to report on the protest. The local MAS-IPSP chapter had been enmeshed in internal quarrels with the consulate, and some of its members individually supported the protest.

Although the consulate lacks the economic resources to buy the support of an association, it can offer preferential treatment in three essential ways. First, the consul can write recommendation letters that help associations solicit access to event rooms or public spaces. Since most associations in Barcelona have no space of their own, they often rely on these public venues. Second, cultural associations frequently perform at consulate events, which are opportunities to perform in front of larger audiences and gain publicity. Third, associations that organize events including 'un acto oficial,' with the consul appearing before the audience, receive particular appreciation in the Bolivian community. Thus, a good relationship with the consulate can boost the association's likelihood of being invited to perform at consulate events or having the consul present at an event the association organizes. To be sure, many associations in Barcelona have survived and prospered without collaborating with the consulate. Yet migrant leaders who were on good terms with the consul and attended party meetings could hope to fare better. In this sense, the MAS-IPSP deployed a transnational linkage strategy, using the consulate as an outpost to link up with migrant leaders in Barcelona in return for clientelistic rewards. Ultimately, since the vote is secret, the party can hardly control whether associations comply with the informal agreement to procure votes. Controversially, the UN has neither the economic resources to lure migrant associations nor the institutional power to implement a similar linkage by reward' strategy.

Finally, Bolivian parties abstain from establishing their own associations. The Bolivian community in Barcelona would not welcome a politically motivated partisan association. Bolivians prefer grassroots movements or engaging in party activities for political activism. Similarly, Bolivian parties do not pursue any notable co-optation strategies. On the one hand, parties cannot offer to nominate emigrants, as the Bolivian constitution requires candidates for the national assembly to have permanently resided in the country during the 2 years preceding the election (Art. 149). On the other hand, parties' internal appointments to the executive boards are of little attraction to migrant leaders, or simply not offered to them. They are unpaid and are either temporary positions for the election cycle (UN), or restricted to the party's 'old guard' (MAS-IPSP). For all these reasons, Bolivian parties prefer to infiltrate associations on an individual level. So far, this strategy has enabled parties to appeal to broader segments of the electorate despite their lack of resources and credibility. 


\section{Ecuador}

As with Bolivian parties, Ecuadorian parties apply infiltration tactics to penetrate migrant associations in Barcelona. Again, partisans link up with association leaders and members on a personal level, not an institutional one.

Usually we try to be in contact with the leaders, but before we fail altogether we search for others [inside the association]. Often this yields better results because at the end they may mobilize even more [people] than the association leader itself.

José, president CREO Catalonia

Ecuadorian parties also adopt an 'event crasher tactic' to infiltrate cultural and sports events organized by migrant associations. There are numerious Ecuadorian associations who meet every weekend to dance, or do sports together.

Yes, without invitation. We go there just like that - it is open space. For example, if there is a sports association and they do an event we go there, of course very respectfully so they do not throw stones at us because they do not like politics. [laughs]

Guillermo, campaign coordinator Alianza País Barcelona

Ecuadorian parties are particularly successful in infiltrating associations because they additionally adopt co-optation tactics that specifically target leaders from well-known migrant associations. Unlike the Bolivian parties, three of the four Ecuadorian parties in this study have set up a comprehensive and permanent transnational executive committee with multiple internal positions, to which they nominate migrant leaders. Local party representatives from Alianza País, CREO and SUMA each simultaneously hold a presidency in a migrant association. In all cases, this partisan activity was preceded by long-time local engagement in associations. These local migrant leaders are wellpositioned to extend the transnational reach of the parties they represent.

Practically, they [the association leaders and members] are already part of the Alianza País family ( ... ) I just invite them personally, and they come. And it is a matter of talking.

Nilo, vice president Alianza País Europa

Partisans such as Nilo frequently participate in cultural community events, which serve as occasions to mobilize voters before elections. In the case of CREO Catalonia, the president's association served as a recruitment pool for campaign volunteers, who would join the campaign in a personal capacity. Parties succeed in co-opting migrant leaders with party positions despite the lack of pay. Alianza País has been particularly successful in this regard. Several migrant leaders I interviewed have formed part of Alianza País' executive board or have been invited to join it at some point. The party's diaspora outreach appeared very attractive to many association leaders.

At a time, the discourse of the president, Rafael Correa, was what we, the associations, wanted to hear because he offered to improve the situation of the 
Ecuadorians residing abroad.

Alba, president FeelCat / campaign coordinator Alianza País Catalonia/Baleares 2013

This discourse has been accompanied by an extensive diaspora policy framework, although many projects have fallen short of expectations (see also Margheritis 2016 Ch. 4, 8). One of the more prolific innovations was a modification of the electoral system to reserve two seats in the National Assembly for emigrant candidates from Europe, Oceania, and Asia. This institutional feature has shaped parties' linkage strategies ever since. Parties offer these prestigious candidacy positions to migrant leaders whom they wish to win over; all four parties included in this study have utilized this co-optation approach. Findings show that more than half of the candidates had an association trajectory (see Table 3). Although candidates resided in different localities (Spain and Italy) ${ }^{2}$ the combination of associative engagement and political commitment was a common feature. Fieldwork showed that smaller, less institutionalized parties also approach migrant leaders with list places for the legislative elections. For example, in 2017, the president of the Federación de Asociaciones de Ecuatorianos en Catalunya (FAEC) ran for Centro Democrático. These co-optation efforts present opportunities for migrants to infiltrate parties and voice their demands.

They [the party] wanted that I represent them. I told them 'I don't have the money to run as a candidate'. [They said] 'no worries, we support you'. And I told them my conditions. ( ... ) They accepted my idea, and well also that I ran independently, not affiliated.

Candidate for Europe, Oceania, and Asia

Table 3 Ecuadorian Candidates for the Constituency Europe, Asia, Oceania, 2013-2017

\begin{tabular}{|c|c|c|c|c|}
\hline \multirow{2}{*}{$\begin{array}{l}\text { Election } \\
\text { Year }\end{array}$} & \multirow[t]{2}{*}{ Candidate } & \multirow[t]{2}{*}{ Political Party } & \multicolumn{2}{|c|}{ Association Board Member } \\
\hline & & & Yes & No \\
\hline \multirow[t]{6}{*}{2017} & Esther Cuesta (e) & Alianza País & & $x$ \\
\hline & Esteban Melo (e) & Alianza País & $x$ & \\
\hline & Jorge Rivera & CREO/SUMA & & $x$ \\
\hline & Maria Rendon & CREO/SUMA & & $x$ \\
\hline & Carlos Romero & Partido Social Cristiano & $x$ & \\
\hline & Tatiana Candell & Partido Social Cristiano & $x$ & \\
\hline \multirow[t]{8}{*}{2013} & Dora Aguirre (e) & Alianza País & $x$ & \\
\hline & Esteban Melo (e) & Alianza País & $x$ & \\
\hline & Katty Bone Barzola & CREO & & $x$ \\
\hline & Edger Piñaloza Vega & CREO & $x$ & \\
\hline & Saul Mora & SUMA & $x$ & \\
\hline & Martha Macías Cedeño & SUMA & & $x$ \\
\hline & Pedro Duart & Partido Social Cristiano & & $x$ \\
\hline & Yessenia Enriquez & Partido Social Cristiano & $x$ & \\
\hline
\end{tabular}


Candidate tickets may appeal more to migrant leaders than internal party posts because assembly members enjoy more room for maneuvering, not to mention prestige and a fixed salary.

Nominating an association leader as a candidate or a party representative helps obtain their full commitment. It also helps parties encourage association figures to contribute their resources and wider network to campaign purposes, including gathering support from leaders of other migrant associations who individually assist in their campaigns.

They [the association leaders] themselves mobilized their people, covered transportation costs and things like that.

Candidate for Europe, Oceania, and Asia

Nevertheless, parties abroad do not co-opt other organizations "to diminish the influence of the groups incorporated" (Schwartz 2005, p. 42), but rather to use them as local assets. Parties aim to extend their reach to community members who are emotionally or formally tied to the association. The recruitment of an association board member as a candidate or party official creates an associative connection between a party and a migrant association. While local norms and the associations' ethos prevent community leaders from tying their association to a political party, Ecuadorian parties circumvent this obstacle by recruiting association board members as candidates or party officials. Both actors avoid an institutional partnership, while the general public mentally link the two organizations.

They say the association is working with the party and they say Annabell Intriago is with Alianza País [...]. They do not define you as Annabell Intriago, they rather define you as an association. For example, they say 'go to the association of Annabell.' Annabell, president Asociación de Ecuatorianos en Catalunya (AEC) / former board member of Alianza País Barcelona

Another linkage strategy Ecuadorian parties use is to offer exchange relationships. Unlike Bolivian parties, Ecuadorian parties use this strategy frequently, yet without capitalizing on the consulate. They invite cultural associations to perform at campaign events. While some associations consider their appearance apolitical, others acknowledge that they form part of a political campaign, but the benefits (publicity) outweigh the possible costs (associative relationship). At times, some parties pay associations a small fee. At least one Ecuadorian dance association clearly stated in the interview to have been financially compensated for their performances at campaign events.

The electoral system offers additional avenues for collaboration. Candidates in the extra-territorial constituency are obliged to present an electoral program. Some of these programs include specific policy pledges to court migrant associations. Parties promise to "create (...) spaces for the events and meetings of associations" (SUMA, Electoral Program 2013), to "bolster the funding of Ecuadorian social organizations abroad via access to competitive funds for cultural and sports activities" (Alianza País, Campaign Webpage 2017), or "that the government recognizes all the associations or federations, (...), and if possible to support them economically" (CREO, Electoral Program 2013). 
Thanks to personal connections between migrant leaders and party representatives, the landscape of Ecuadorian associations in Barcelona frequently intersects with the world of political home country parties. Association leaders are committed to maintaining the separation. Perhaps ironically, it is precisely the political involvement of the Ecuadorian association leaders that prevents political parties from forging formal alliances with associations (Schwartz 2005) or establishing their own associations in Barcelona (Poguntke 2006; Verge 2012). As in the Bolivian case, local context precludes formal connections between associations and home country parties. In both cases, parties therefore infiltrate associations informally, crashing cultural or sport events and using their personal networks to reach potential voters. Parties benefit from migrants who have a foot in both worlds and can easily move between the two.

While all Bolivian and Ecuadorian parties execute their linkage strategies in a similarly informal way, important differences exist in the types of tactics they use. Ecuadorian parties co-opt extensively. The electoral system provides for extra-territorial assembly seats and encourages parties to set up a transnational executive board. Parties use these structures to co-opt board members from renowned migrant associations. In turn, parties become more vulnerable to infiltration by association members who seek to elevate migrant demands. In contrast, Bolivian law prohibits parties from fielding emigrant candidates. Furthermore, Bolivian parties struggle to offer collaborative linkages, as politicians often fail to meet the demands of migrant associations and face distrust abroad. Unlike Ecuadorian parties, they cannot offer candidacies for extraterritorial districts with specific party programs tailored to associations.

The Ecuadorian case indicates that parties can use these electoral programs to create a trustworthy, migrant-centered image on which association leaders can rely. However, parties in government may overcome these resource deficits by offering linkages by reward (Lawson 1980). Bolivia's MAS-IPSP planted loyal party members in key consulate positions, who then informally linked up with migrant association leaders, offering rewards in exchange for potential electoral support. In contrast, Alianza País largely refrained from politicizing the consulate in Barcelona during its reign. Arguably, the Ecuadorian electoral system provided sufficient resources to render clientelist tactics unnecessary. Thus, the political system of the home country is key to understanding parties' transnational campaign strategies.

\section{Conclusions}

Transnational electoral campaigns have become a global phenomenon. This paper has analyzed the hurdles Latin American parties face when campaigning across continents and the strategies they have developed in response. I have situated this discussion within the literature on political transnationalism and party interest groups.

In the domestic electoral arena, political parties commonly use five strategies to link up with interest organizations: 1) formal alliances, 2) establishing their own groups, 3) infiltration, 4) co-optation, 5) exchange relationships. Drawing on qualitative interview material and several participant observations, this study investigated the extent to which parties apply these strategies in their transnational election campaigns, and how they execute them on the ground. The results demonstrate that the linkage strategies of parties abroad largely resemble the ones deployed at home. Yet the transnational context influences the strategies chosen and constrains how parties apply them in practice. 
All political parties in this study refrain from forging formal alliances with associations or creating their own associations. This stands in stark contrast to what the party behavior literature has documented and suggested thus far (Allern 2010; Poguntke 2006; Schwartz 2005; Verge 2012). Yet, in line with the literature, parties do infiltrate and co-opt migrant organizations (Schwartz 2005; Verge 2012). However, this study identifies important differences between tactics deployed by parties from different countries. These differences can be traced back to the different electoral systems in each country of origin. This finding strengthens previous research demonstrating that the electoral system determines cross-country variance in party outreach (Kernalegenn and van Haute 2020; Østergaard-Nielsen and Ciornei 2019). That said, parties seem to differ in their outreach strategies much more across contexts than across different party ideologies or families. In fact, parties in both countries behave remarkably similarly, though incumbent parties may have certain advantages. Most importantly, only Ecuadorian parties use co-optation tactics. Hence, this study largely confirms the 'reach and depth' hypothesis of Verge (2012). The more political appointments are available to parties, the more they will use them to co-opt civic society organizations.

Transnational co-optation tactics are no isolated phenomenon. Mexican parties in Chicago have placed migrant organization leaders in charge of the local party headquarters (Schütze 2016, pp. 119-123). Italian parties have courted migrant organization leaders with extra-territorial candidate seats (Lafleur 2013, pp. 126-127), and Turkish parties have included association leaders from Germany on domestic party lists (Østergaard-Nielsen 2003, pp. 112-113; Yener-Roderburg 2020, p. 230).

Moreover, this analysis reveals that the political culture is an important determinant of party behavior beyond the domestic electoral arena (Thomas 2001). The local residency context significantly shapes how parties seek to gain visibility abroad. This study has demonstrated that local context defines whether parties execute their linkage strategies formally or informally. In Barcelona, home country parties infiltrate, co-opt and collaborate with associations informally. Controversially, scholars considered these informal connections to be 'weaker links' (Allern 2010, p. 59), and less 'effective' (Poguntke 2006, p. 399), yet abroad, these informal ties can gain particular strength. As this study has highlighted, sometimes informal links can be the only way for political parties to connect with interest groups at all.

\footnotetext{
Acknowledgements

I wish to extend my gratitude to the editors of this special Issue, Emilie van Haute and Tudi Kernalegenn, as well as the participants at the "Political Parties Abroad. A New Arena for Citizenship?" conference held at Université Catholique de Louvain in April 2018 for their suggestions and valuable feedback. I also would like to thank the three anonymous reviewers for their constructive comments. Moreover, I am thankful to Pau Palop-García who discussed an earlier version of this article at the IMISCOE conference held at the Universitat Pompeu Fabra Barcelona in June 2018, as well as the participants who attended the panel. Finally, this research has been supported by the Institute of Government and Public Policy (IGOP), based at the Autonomous University of Barcelona (UAB), who has hosted me during the fieldwork.
}

Author's contributions

NF is the sole author of this article. The author read and approved the final manuscript.

Funding

Not applicable.

Availability of data and materials

Data are not available in order to protect the research participants. 
Received: 20 May 2020 Accepted: 2 February 2021

Published online: 25 May 2021

\section{References}

ACE. (2019). ACE Electoral Knowledge Network Website. http://aceproject.org. Accessed 13 Apr 2018

Allern, E. H. (2010). Political parties and interest groups in Norway. Colchester: ECPR Press.

Bermúdez, A. (2016). International migration, transnational politics and conflict. The Gendered Experience of Colombian Migrants in Europe. London: Palgrave Mcmillan.

Burgess, K. (2012). Collective remittances and migrant-state collaboration in Mexico and El Salvador. Latin American Politics and Society, 54(4), 119-146

Burgess, K. (2018). States or parties? Emigrant outreach and transnational engagement. International Political Science Review, 39(3), 369-383.

Cebolla-Boado, H., \& López-Sala, A. (2015). Transnational immigrant organisations in Spain: Their role in development and integration. In A. Portes, \& P. Fernández-Kelly (Eds.), The state and the grassroots: Immigrant transnational organizations in four continents (pp. 264-290). New York: Berghahn Books.

Collyer, M. (2014). A geography of extra-territorial citizenship: Explanations of external voting. Migration Studies, 2(1), 55-72.

Consejo Nacional Electoral Ecuador CNE. (2018). Electoral Commission's Webpage. https://app03.cne.gob.ec/EstadisticaCNE/A mbito/Index.aspx. Accessed 28 May 2018

Dalton, R., \& Wattenberg, M. (2002). Parties without partisans: Political change in advanced industrial democracies. Oxford: Oxford University Press.

Dogan, M., \& Pelassy, D. (1984). How to compare nations. Strategies in Comparative Politics. New Jersey: Chatham House Publications Inc

Escobar, C. (2010). Exploring transnational civil society a comparative study of Colombian Dominican and Mexican immigrant organizations in the USA. Journal of Civil Society, 6(3), 205-235.

Escobar, C., \& Gómez Kopp, M. (2014). El voto en el exterior: Estudio comparativo de las elecciones colombianas legislativas y presidenciales de 2010. Bogotá: Universidad Externado de Colombia.

Escrivá, Á., Santa Cruz, U., Bermúdez, A., \& Ortega Breña, M. (2010). Migration, gender, and politics: The 2006 Peruvian elections abroad. Latin American Perspectives, 37(5), 106-120.

Freedom House Index. (2018). Freedom in the world 2018. Democracy in Crisis.

Hammond, L. (2012). The absent but active constituency: The role of the Somaliland UK Community in election politics. In T. Lyons, \& P. Mandaville (Eds.), Politics from Afar. Transnational diasporas and networks (pp. 157-180). London: Hurst \& Company.

Hinojosa, A. (2008). España en el itinerario de Bolivia. Migración transnacional, género y familia en Cochabamba. In S. Novick (Ed.), Las migraciones en América Latina (pp. 93-112). Buenos Aires: CLACSO.

Hinojosa, A. (2009). Migración boliviana a España: antecedentes, caracterización y perspectivas. In H. Mazurek (Ed.), Migraciones contemporáneas: Contribución al debate (pp. 157-180). La Paz: CIDES-UMSA.

Instituto Nacional de España INE. (2016). INE Webpage. https://www.ine.es. Accessed 20 Oct 2018.

Itzigsohn, J. (2000). Immigration and the boundaries of citizenship: The institutions of immigrants' political transnationalism. International Migration Review, 34(4), 1126-1154.

Kernalegenn, T., \& van Haute, E. (Eds.) (2020). Political Parties Abroad: A new Arena for Party Politics. New York: Routledge.

Kirchheimer, O. (1966). The transformation of the Western European party systems. In J. La Palombara \& M. Weiner (Eds.), Political Parties and Political Development (pp. 177-200). Princeton: Princeton University Press.

Kitschelt, H. (1989). The logics of party formation. Ecological parties in Belgium and West Germany. New York: Cornell University Press.

Klekowski von Koppenfels, A. (2013). Political transnationalism in a new light. In D. Halm, \& Z. Sezgin (Eds.), Migration and organized civil society. Rethinking national policy (pp. 79-95). London: Routledge.

Koslowski, R. (2005). International migration and the globalization of domestic politics: A conceptual framework. In R. Koslowski (Ed.), International migration and the globalization of domestic politics (pp. 5-33). New York: Routledge.

Lafleur, J.-M. (2013). Transnational politics and the state. The external voting rights of diasporas. London: Routledge.

Landolt, P., Autler, L., \& Baires, S. (1999). From Hermano Lejano to Hermano mayor: The dialectics of Salvadoran transnationalism. Ethnic and Racial Studies, 22(2), 290-315.

Lawson, K. (1980). Political parties and linkage: A comparative perspective. New Haven: Yale University Press.

Levitsky, S., Loxton, J., van Dyck, B., \& Domínguez, J. (2016). Challenges of party-building in Latin America. New York: Cambridge University Press.

Levitt, P. (2001). The transnational villagers. Berkeley: University of California Press.

Mainwaring, S. (Ed.) (2018). Party Systems in Latin America: Institutionalization, decay, and collapse. Cambridge: Cambridge University Press.

Margheritis, A. (2016). Migration governance across regions. State-diaspora relations in the Latin American-Southern Europe Corridor. New York: Routledge.

Morales, L., \& Jorba, L. (2010). Transnational links and practices of migrants' organisations in Spain. In T. Faist \& R. Bauböck (Eds.), Diaspora and transnationalism. Concepts, theories and methods (pp. 267-349). Amsterdam: Amsterdam University Press.

Morell Blanch, A. (2005). The role of immigrant associations in the host society: Theoretical questions and empirical evidence. Migraciones, 17, 111-142.

Mügge, L. (2010). Beyond Dutch Borders. Transnational politics among colonial migrants, guest workers and the second generation. Amsterdam: Amsterdam University Press.

Norris, P., \& Grömping, M. (2019). Perceptions of electoral integrity (PEl-7.0). Harvard Dataverse, V2, UNF:6:2wnukYraCZzg+ gojPE/ljg== [fileUNF]. https://doi.org/10.7910/DVN/PDYRWL

Organo Electoral Plurinacional Bolivia OEP. (2018). Electoral Commission's Webpage. http://www.oep.org.bo

Østergaard-Nielsen, E. (2003). Transnational politics. Turks and Kurds in Germany. London: Routledge. 
Østergaard-Nielsen, E., \& Ciornei, I. (2019). Political parties and the transnational mobilisation of the emigrant vote. West European Politics, 42(3), 618-644.

Paarlberg, M. (2019). Competing for the diaspora's influence at home: Party structure and transnational campaign activity in El Salvador. Journal of Ethnic and Migration Studies, 45(4), 539-560.

Palop-García, P., \& Pedroza, L. (2017). Beyond convergence: unveiling variations of external franchise in Latin America and the Caribbean from 1950 to 2015. Journal of Ethnic and Migration Studies, 43(9), 1597-1616.

Poguntke, T. (2006). Political parties and other organizations. In R. Katz, \& W. Crotty (Eds.), Handbook of party politics (pp. 396405). London: SAGE.

Portes, A., \& Fernández-Kelly, P. (2015). The state and the grassroots: Immigrant transnational organizations in four continents. Oxford: Berghahn Books.

Scarrow, S. E., Webb, P., \& Poguntke, T. (2017). Organizing political parties: Representation, participation, and power. Oxford: Oxford University Press.

Schütze, S. (2016). Constructing transnational political spaces: The multifaceted political activism of Mexican migrants. London: Palgrave Mcmillan.

Schwartz, M. (2005). Linkage processes in party networks. In A. Römmele, D. Farrell, \& P. Ignazi (Eds.), Political parties and political systems. The concept of linkage revisited (pp. 37-60). Westport: Praeger.

Shain, Y. (1989). The frontier of loyalty: Political exiles in the age of the nation-state. Middletown: Wesleyan University Press.

Smith, M. P., \& Bakker, M. (2008). Citizenship across Borders. The political transnationalism of El Migrante. New York: Cornell University Press.

Smith, R. C. (2003). Migrant membership as an instituted process: Transnationalization, the state and the extra-territorial conduct of Mexican politics. International Migration Review, 37(2), 297-343.

Thomas, C. (Ed.) (2001). Political Parties and Interest Groups: Shaping Democratic Governance. Boulder: Lynne Rienner.

United Nations. (2015). Trends in international migrant stock: Migrants by destination and origin (United Nations database, POP/DB/MIG/stock/rev.2015).

Verge, T. (2012). Party strategies towards civil society in new democracies: The Spanish case. Party Politics, 18(1), 45-60.

World Bank. (2018a). Gini Index (World Bank estimate). https://data.worldbank.org/indicator/SI.POV.GINI

World Bank. (2018b). Personal remittances, received (\% of GDP).

Yener-Roderburg, I. Ö. (2020). Party organizations across borders. Top-down satellites and bottom-up alliances. The case of AKP and HDP in Germany. In T. Kernalegenn, \& E. van Haute (Eds.), Political parties abroad: A new arena for party politics (pp. 218-237). New York: Routledge.

\section{Publisher's Note}

Springer Nature remains neutral with regard to jurisdictional claims in published maps and institutional affiliations.

\section{Submit your manuscript to a SpringerOpen ${ }^{\circ}$ journal and benefit from:}

- Convenient online submission

- Rigorous peer review

- Open access: articles freely available online

- High visibility within the field

- Retaining the copyright to your article

Submit your next manuscript at $\boldsymbol{\nabla}$ springeropen.com 